\title{
THE IMPLEMENTATION OF 5S MANAGEMENT AT OFFSET UNIT: CASE STUDY AT PT PURRA BARUTAMA, KUDUS
}

\section{IMPLEMENTASI MANAJEMEN 5R (RINGKAS, RAPI, RESIK, RAWAT DAN RAJIN) PADA UNIT OFFSET: STUDI KASUS DI PT PURA BARUTAMA KUDUS}

\author{
Tamado Simbolon $^{\mathrm{a}^{*}}$ MT Djamara ${ }^{\mathrm{a}}$, Antinah Latif ${ }^{\mathrm{a}}$ \\ ${ }^{a}$ Teknik Grafika, Politeknik Negeri Media Kreatif, Indonesia \\ *Email: tamadosimbolon7@gmail.com
}

\begin{abstract}
Companies that have poor performance can be seen from the irregular work situation, the number of project items or reworks, the bad employee attendance scores and so on. How to implement the $5 R$, because the $5 R$ is a management system in maintaining order, efficiency and discipline in the workplace, as well as increasing overall company performance. $5 R$ is the first indicator to assess the good and bad performance of a company. However, it is unfortunate that not all companies understand the importance of (K3) and how to implement it in a corporate environment. The writing method used is descriptive method. The purpose of writing: To determine employee understanding of the $5 R$ program in Occupational Safety and Health, to determine the implementation of the $5 R$ program in Occupational Safety and Health which is run at PT. Pura Barutama Kudus Offset Unit, to find out the implementation of the $5 R$ program in controlling Occupational Safety and Health which is carried out by PT Pura Barutama Kudus Offset Unit. Based on the observation that 5R management must always be improved.
\end{abstract}

\section{Keywords: 5S, OHS, Printing Industry}

\begin{abstract}
Abstrak- Perusahaan yang mempunyai kinerja buruk dapat dilihat dari situasi kerja yang tidak teratur, banyaknya barang riject arau rework, nilai absensi karyawan yang buruk dan sebagainya. Cara menerapkan 5R, karena 5R merupakan sistem manajemen dalam memelihara ketertiban, efisiensi dan disiplin di tempat kerja, sekaligus meningkatan kinerja perusahaan secara menyeluruh. 5R merupakan indikator pertama untuk menilai baik dan buruknya kinerja sebuah perusahaan. Namun patut disayangkan tidak semua perusahaan memahami arti pentingnya (K3) dan bagaiman mengimplementasikannya dalam lingkungan perusahaan. Metode Penulisan yang digunakan adalah metode deskriptif. Tujuan penulisan: Untuk mengetahui pemahaman karyawan terhadap program 5R dalam Keselamatan dan Kesehatan Kerja, untuk mengetahui penerapan program 5R dalam Keselamatan dan Kesehatan Kerja yang dijalankan di PT. Pura Barutama Unit Ofset Kudus, untuk mengetahui pelaksanaan program 5R dalam pengendalian Keselamatan dan Kesehatan Kerja yang dijalankan oleh PT Pura Barutama Unit Ofset Kudus. Berdasarkan hasil pengamatan bahwa manajemen 5R harus selalu ditingkatkan.
\end{abstract}




\section{Kata Kunci: K3, 5R, Industri Grafika}

\section{PENDAHULUAN}

Perubahan zaman yang semakin maju dan perkembangan teknologi yang semakin canggih menghasilkan berbagai inovasi dalam berbagai bidang kehidupan, termasuk bidang industri. Kemajuan Ini memberikan banyak manfaat bila dapat dinikmati oleh banyak pihak (Kristanto Jahja, Kemajuan Industri 2009). Perubahan dunia industri semakin cepat, semakin banyak pula tuntutan kerja yang diinginkan perusahaan. Untuk mendukung pekerjaan agar dapat dilakukan lebih mudah dan lebih nyaman, salah satu yang harus dibangun adalah budaya kerja. Budaya kerja di perusahaan perlu diciptakan dan dibutuhkan untuk perkembangan perusahaan dimasa yang akan datang dalam menghadapi tantangan di dunia industri. Perusahaan yang bergerak dalam proses packaging memerlukan iklim kerja yang baik karena didalamnya terdapat sebuah proses produksi yang saling berkaitan antar lini. Proses produksi harus mengedapankan asasasas efektifitas kerja, efisiensi untuk meningkatkan produktifitas dan keselamatan kerja agar produk yang dihasilkan memenuhi standar yang ditetapkan.

$$
\text { Setiap perusahaan tentu }
$$
mengharapkan sebuah kondisi yang bersih dan rapi. Di mana setiap pekerja memiliki konsistensi yang tinggi terhadap kedisiplinan diri. Tujuannya tentu untuk mendukung tercapainya tingkat efisiensi serta produktivitas yang tinggi dalam perusahaan tersebut, akan tetapi untuk mewujudkan kondisi tersebut bukanlah hal yang mudah untuk dilakukan. Masalah yang sering dihadapi perusahaan yaitu sulitnya mencari data atau sarana yang lupa akan penempatannya. Tidak hanya itu saja, berkas kerja juga sering berantakan dan tidak rapi. Hal-hal tersebut tentu dapat memicu emosi dari pekerja itu sendiri. Oleh karena itu diperlukannya 5R agar tercipta kondisi kerja yang lebih produktivitas dan efektif. 5R sendiri yaitu program yang di adaptasi dari program 5S (Seiri, Seiton, Seiso, Seiketsu, Shitsuke) dari Jepang. Program 5S ini sudah dikembangkan di Jepang dan negara-negara lainnya. Di Indonesia sendiri menerapkan program 5R (Ringkas, Rapi, Resik, Rawat, Rajin) yang mengadaptasi dari program $5 \mathrm{~S}$. Program ini cukup sederhana, yaitu melakukan penataan dan pembersihan tempat kerja seperti yang diterapkan di Jepang. Pengertian 5R yaitu budaya bagaimana seseorang mengatur atau memperlakukan tempat kerjanya dengan benar. Jika tempat kerjanya, rapi, tertib dan bersih tentunya kondisi kerja akan menjadi lebih produktif 
dan efektif.

Implementasi manajemen 5R dalam K3 di PT Pura Barutama Unit Ofset berawal dari tahun 2016 berdasarkan kebijakan manajemen head office PT Pura Barutama Kudus. Setelah mendapatkan kebijakan tersebut, PT Pura Barutama Unit Ofset langsung membuat struktur 5R dan membuat rapat. Rapat pertama yang dibahas adalah memisahkan barang-barang yang masih digunakan dan sudah tidak digunakan untuk dilakukan pembersihan. Rapat selanjutnya membahas program-program mulai dari penerapan $5 \mathrm{R}$ sampai pengendalian program $5 R$.

PT. Pura Barutama Unit Ofset salah satu adalah perusahaan yang bergerak di bidang percetakan packaging. Perusahaan ini membudayakan "budaya 5R", tujuannya untuk mengimplementasikan efektifitas kerja, efisiensi, produktifitas, keselamatan dan kesehatan kerja diperlukan aspek 5S dari Jepang yang terdiri dari Seiri, Seiton, Seiso, Seiketsu dan Shitsuke. 5S diartikan ke dalam bahasa Indonesia menjadi 5R yaitu: Ringkas, Rapi, Resik, Rawat dan Rajin.

Pada prakteknya penerapan 5R tidaklah sulit, tetapi banyak perusahaan atau organisasi gagal menerapkan 5R, banyak fungsional perusahaan bahkan pimpinan yang tidak memahami makna dan tujuan sesungguhnya dari 5R, Mereka beranggapan bahwa 5R menjadi tanggung jawab karyawan saja. Padahal keberhasilan penerapan 5R berhubungan dengan seluruh sumber daya manusia dalam organisasi, dari puncak pimpinan hingga perkerja paling bawah.

Perusahaan yang mempunyai kinerja buruk dapat dilihat dari situasi kerja yang tidak teratur, banyaknya barang riject arau rework, nilai absensi karyawan yang buruk dan sebagainya. Untuk menanggulangi hal tersebut adalah dengan cara menerapkan 5R, karna 5R merupakan sistem manajemen dalam memelihara ketertiban, efisiensi dan disiplin di tempat kerja, sekaligus meningkatan kinerja perusahaan secara menyeluruh. 5R merupakan indikator pertama untuk menilai baik dan buruknya kinerja sebuah perusahaan.

"Program 5R diharapkan untuk menghilangkan pemborosan yang ada dapat diminimalkan sehingga terjadi peningkatan produktifitas dan efektivitas dari perusahaan" (Osada, Metode 5R, 2011).

"Metode 5R merupakan tahap untuk mengatur kondisi tempat kerja yang berdampak terhadap efektifitas kerja, efisiensi, produktifitas dan keselamatan kerja yang merupakan salah satu cara menciptakan suasana kerja yang nyaman adalah perusahaan menerapkan sikap kerja 5R" (Kristanto Jahja, Kemajuan Industri, 2009). Lingkungan kerja yang sebelumnya 
kurang nyaman bagi pekerja dapat diperbaiki dan disusun dibuat sedemikian rupa menjadi aman, nyaman bagi pekerja. Hal ini dituangkan dalam program 5R yang sudah menjadi terapan di PT. Pura Barutama Unit Ofset. 5R berpengaruh langsung terhadap produktivitas. Percaya atau tidak akan kita buktikan dalam pembahasan berikutnya.

Upaya peningkatan produktivitas dewasa ini telah menajadi idaman setiap perusahaan. Konsep (Industrial Engineering), Total Productive Maintance (TPM) dan Just In Time (JIT) sangat populer dikalangan praktisi sebagai alat peningkatan produktivitas, tetapi di dalam prakteknya tidak jarang menyimpang dari sasaran yang diharapkan. Dorongan keinginan mendapatkan hasil yang besar dalam waktu yang relatif pendek, telah menyebabkan sebagian besar para manajer perusahaan mengadakan lompatan dalam usaha peningkatan produktivitas.

5R memberi dasar perubahan sikap, tingkah laku atau pola pikir manajemen dan pekerja terhadap peningkatan $5 \mathrm{R}$ memberi dasar perubahan sikap, tingkah laku atau pola pikir manajemen dan pekerja terhadap peningkatan produktivitas dengan prinsip KAIZEN yaitu perbaikan sedikit demi sedikit secara bertahap tapi terus menerus. Dengan menerapkan 5R secara konsisten dan membangun sebuah komitmen bersama seluruh elemen di perusahaan, paling tidak akan diperoleh keuntungan antara lain : Zero Waste (Mengurangi Biaya dan Efisiensi Meningkat), Zero Injury (Keselamatan kerja lebih baik), Zero Breakdown (Perawatan lebih baik), Zero Defect (Kualitas lebih baik), Zero Set-up time (Tidak ada waktu yang terbuang), Zero Late Delivery (memenuhi permintaan pelanggan tepat pada waktunya), Zero Customer Claim (mendapat Kepercayaan yang tinggi dari pelanggan), Zero Deficit (perusahaan tambah maju).

Berdasarkan hal tersebut di atas, Penulis mengangkat judul "Implementasi Manajemen 5R (Ringkas, Rapi, Resik, Rawat dan Rajin) Pada Unit Offset: Gambaran di PT Pura Barutama, Kudus.

Identifikasi Masalah : Berdasarkan latar belakang dalam penulisan, maka penulis mengidentifiasi sebagai berikut :

Masih sedikitnya pemahaman karyawan terhadap program 5R dalam Keselamatan dan Kesehatan Kerja di PT. Pura Barutama pada Unit Offset; Penerapan program 5R dalam Keselamatan dan Kesehatan Kerja di PT. Pura Barutama Unit Ofset; Aktivitas pelaksanaan program $5 \mathrm{R}$ dalam pengendalian Keselamatan dan Kesehatan Kerja yang dijalankan di PT. Pura Barutama.

\section{Rumusan Masalah :}

1. Bagaimana gambaran perusahaan tersebut? 
2. Bagaimana pemahaman karyawan terhadap program 5R dalam Keselamatan dan Kesehatan Kerja di PT Pura Barutama terutama di bagian Offset/cetak?

3. Bagaimana penerapan program $5 \mathrm{R}$ dalam Keselamatan dan Kesehatan Kerja di PT Pura Barutama terutama di bagian Offset/cetak?

4. Bagaimana aktivitas pelaksanaan program 5R dalam pengendalian Keselamatan dan Kesehatan Kerja yang dijalankan oleh PT Pura Barutama terutama di bagian Offset/cetak?

\section{Pembatasan Masalah}

Penulis membatasi masalah sebagai berikut: Pemahaman karyawan terhadap program 5R dalam Keselamatan dan Kesehatan Kerja di PT Pura Barutama Unit Ofset Kudus pada bagian produksi; Penerapan program 5R dalam Keselamatan dan Kesehatan Kerja di PT Pura Barutama Unit Ofset Kudus dalam bentuk manajemen pelaksanaan dan pengendalian. Dan Aktivitas pelaksanaan program $5 \mathrm{R}$ dalam pengendalian Keselamatan dan Kesehatan Kerja yang dijalankan oleh PT Pura Barutama.

\section{Tujuan Penulisan :}

1. Untuk mengetahui gambaran perusahaan tersebut
2. Untuk mengetahui pemahaman karyawan terhadap program 5R dalam Keselamatan dan Kesehatan Kerja

3. Untuk mengetahui penerapan program $5 R$ Keselamatan dan Kesehatan Kerja di PT Pura Barutama Unit Ofset Kudus

4. Untuk mengetahui pelaksanaan program 5R dalam pengendalian Keselamatan dan Kesehatan Kerja yang dijalankan oleh PT Pura Barutama Unit Ofset Kudus

\section{Manfaat penulisan :}

Manfaat adanya pembahasan tentang "Implementasi manajemen 5R dalam Keselamatan dan Kesehatan Kerja di PT Pura Barutama Unit Ofset Kudus" yaitu untuk menerapkan suatu sistem guna untuk mencapai suatu efektivitas kerja, efisiensi, produktivitas dan Keselamatan Kerja

\section{Bagi penulis}

Dapat meningkatkan pengetahuan dan keterampilan dalam memahami manajemen 5R dalam Keselamatan dan Kesehatan Kerja.

\section{Bagi Industri}

Dapat memberi masukan pada perusahaan mengenai aspek 5R dalam K3 dan informasi tentang kondisi lingkungan kerja sebagai acuan perbaikan lingkungan kerja. 


\section{METODE PENELITIAN}

Metode penulisan yang penulis gunakan pada Tugas Akhir ini menggunakan metode deskriptif. Hal ini dimaksudkan untuk mendapatkan data yang kuat dan akurat dalam pembuktiaannya serta dapat memberikan solusi yang tepat pada masalah yang terjadi. Beberapa teknik pengumpulan data yang penulis gunakan yaitu sebagai berikut.

\section{Metode Kepustakaan}

Dengan metode ini penulis memperoleh data dengan membaca, mengumpulkan dan menelaah sumbersumber bahan bacaan yang diperlukan dalam penulisan laporan ini yang berasal dari bahanbahan refrensi seperti buku, diktat kuliah, internet, makalah-makalah maupun sumbersumber lainnya, yang bersangkutan dengan tema penulis ambil guna membantu dalam penyelesaian penulisan praktik industri ini.

\section{Metode Observasi}

Penulis mengumpulkan data dengan cara observasi lapangan atau mengamati proses dan kegiatan yang sedang berlangsung, ketika melakukan praktik industri di PT. Pura Barutama Unit Ofset Kudus untuk mendapatkan data yang dibutuhkan dalam penyelesaian Tugas Akhir ini.

\section{Metode Wawancara}

Penulis melakukan wawancara dan diskusi dengan pihak-pihak yang terkait yang berhubungan dengan obyek penelitian guna memperoleh penjelasan mengenai data yang akurat dan jelas serta mendapatkan solusi terbaik dalam memecahkan masalah yang ada.

\section{Tempat Penelitian}

Penelitian ini dilakukan di Unit Offset/ cetak di PT Pura Barutama, Kudus.

\section{Ruang Lingkup Penelitian}

Penelitian ini dilakukan di Unit Cetak PT Pura Barutama, Kudus dengan focus pada manajement 5R. Metode penelitian dengan deskripsi, cara pengambilan data melalui observasi, wawancara, dan kepustakaan. Waktu penelitian dilakukan selama proses magang kurang lebih selama 3 bulan di Perusahaan tersebut.

\section{HASIL DAN PEMBAHASAN}

Gambaran Perusahaan dan Gambaran K3 PT Pura Barutama adalah perusahaan swasta yang bergerak dibidang percetakan dan packaging. Pemilik dari PT Pura Barutama adalah Bapak Jacobus Busono. Perusahaan percetakan ini berlokasi di Jalan Kresna, Kec. Jati, Kab. Kudus, Jawa Tengah. Sebagai perusahaan percetakan terkenal di Jawa Tengah, Indonesia hingga Internasional, PT Pura Barutama selalu menjaga mutu cetak yang dihasilkan. 
PT Pura Barutama (Perseroan) berdiri pada tahun 1908, pertama kali hanyalah usaha percetakan kecil dengan karyawan yang berjumlah tidak lebih dari 8 orang. Saat ini PT Pura Barutama berkembang menjadi industri percetakan dan pengepakan yang cukup berpengaruh di Asia Tenggara. Menyusul ekspansi secara perlahan namun pasti dan terarah selama bertahun-tahun, PT Pura Barutama kini merupakan kelompok usaha yang terintegrasi secara vertikal dan terdiri dari berbagai divisi atau unit bisnis, diantaranya adalah sistem anti pemalsuan, pembuatan kertas security dan kertas uang, konversi kertas dan film, percetakan dan pengepakan, serta teknologi identifikasi tingkat tinggi.

Sekarang PT Pura Barutama telah berkembang menjadi lebih dari 29 unit di atas lahan seluas lebih dari 65 hektar. Berkantor pusat di Kudus, sekitar 50 kilometer di timur kota Semarang. Unit-unit yang ada diantaranya adalah Pura Ofset, Pura Kertas, Microcapsule, Pura Metalizing, Pura Box, Pura Tinta, Total Security System, Indo Stamping Foil, Pura Rotogravure, dan masih banyak lagi.

Bidang usaha yang dirintis PT Pura Barutama adalah cetak ofset, yang akhirnya berkembang menjadi Unit Ofset. Sudah banyak konsumen yang mempercayai PT Pura Barutama Unit Ofset sebagai rekanan dalam memenuhi kebutuhan permintaan tentang percetakan dan pengepakan, misalnya PT Unilever, PT HM Sampoerna, PT Ceres, PT Campina, PT Fonterra, PT Boehringer, Sanbe Farma, PT Soho, PT Reckitt Benkiser, PT Herlina, PT Eagle Brand, PT Bayer, PT Dexa Medika, dan masih banyak lagi. Kebanyakan dari konsumennya adalah pemimpin pasar Indonesia pada bidangnya masing-masing.

Pada tahun 1970 PT Pura Barutama mencatat tonggak sejarah penting dengan peralihan dari kepemimpinan lama ke kepemimpinan baru di bawah generasi ketiga yaitu Jacobus Busono. Di bawah kepemimpinan dan profesionalisme tim manajemen dan sinergi lebih dari 8.500 karyawan, PT Pura Barutama terus berkembang pesat untuk memasuki pasarpasar baru, baik di dalam maupun di luar negeri.

PT Pura Barutama akan selalu berusaha membuat para konsumen puas dengan menghasilkan produk yang bermutu tinggi dan sesuai dengan permintaan dari konsumen Bahkan dalam proses produksi, PT Pura Barutama unit Ofset dilengkapi dengan mesin-mesin cetak yang modern, berkecepatan tinggi, terkomputerisasi multiwarna, dan juga dilengkapi mesin untuk proses completing yang modern. Selain didukung oleh sumber daya manusia yang 
berpengalaman dan yang sudah terlatih di bidangnya, PT Pura Barutama Unit Ofset juga menawarkan sistem yang profesional yang dapat memenuhi permintaan konsumen, sehingga konsumen merasa senang dapat bekerjasama dengan PT Pura Barutama. Dapat dikatakan bahwa PT Pura Barutama Unit Ofset menjamin mutu produk cetakan untuk memperoleh tampilan kemasan yang bergengsi dan menarik.

Dalam proses produksinya, PT Pura Barutama Unit Ofset tidak menutup kemungkinan untuk bekerjasama dengan unit-unit lain untuk menciptakan produk yang berkualitas tinggi. Dalam pemenuhan bahan baku cetakan, PT Pura Barutama Unit Ofset juga mengambil supply dari PT Pura Barutama Unit Kertas, Unit Paper Mill, maupun unit Total Security System (TSS), meskipun tidak menutup kemungkinan untuk bekerjasama dengan supplier dari luar. Sedangkan untuk bahan baku penunjang seperti tinta selain dari supplier luar, tetap ada andil yang cukup besar dari PT Pura Barutama Unit Tinta. Itu semua tergantung dari permintaan konsumen sendiri, untuk cetakan yang menggunakan hologram PT

Pura Barutama Unit Ofset melakukan kerja sama dari PT Pura Barutama Unit Total Security System. Jasa pengiriman produk dari PT Pura Barutama Unit Ofset kepada konsumen tidak terlepas dari dukungan Pura
Group tepatnya PT Pura Barutama Unit Kendaraan. Begitu pula dalam faktor yang lainnya tidak akan terlepas dari dukungan Pura unit lain, sehingga menjadikan kunci sukses PT Pura Barutama yang bertumpu pada lini produk yang lengkap dan berbasis produksi berkapasitas tinggi

PT. Pura Barutama Unit Ofset sebagai perusahaan ternama yang bergerak di bidang Percetakan dan Kemasan Ofset mempunyai komitmen untuk menjaga dan mengembangkan produk-produk unggulan yang berorientasi pada kualitas, kreativitas atau inovasi, nilai tambah dan keamanan pangan.

Untuk merealisasikannya, segenap karyawan dan manajemen bersepakat memberikan pelayan yang terbaik demi memberi kepuasan pelanggan dengan cara :

- Memberikan produk yang sesuai dengan persyaratan pelanggan dan memenuhi peraturan dan persyaratan berlaku.

- Menerapkan, memelihara, dan secara berkesinambungan meningkatkan sistem manajemen mutu dan keamanan pangan berdasarkan ISO 9001 dan FSSC 22000 dengan menggunakan ISO/TS 22002-4

- Melibatkan pemasok dan mitra kerja perusahaan serta pihak lain yang terkait Menyediakan sumber daya manusia yang kompeten Di dalam penjabarannya, kebijakan ini akan menjadi kerangka 
dalam penetapan sasaran mutu dan keamanan pangan dan selalu dievaluasi kesesuaiannya secara berkala.

\section{Komitmen Kebijakan Keselamatan dan Kesehatan Kerja}

Bahwa Keselamatan dan Kesehatan Kerja merupakan salah satu faktor penting dalam menunjang kelancaran proses produksi. Oleh karena itu semua pekerja yang berada di tempat kerja maupun orang lain yang berada di tempat kerja harus memahami dan aktif ikut serta dalam segala kegiatan yang berwawasan Keselamatan dan Kesehatan Kerja. Kami selaku Pimpinan bertanggung jawab atas pelaksanaan program Keselamatan dan Kesehatan Kerja di lingkungan perusahaan Pura Group, dan untuk itu perusahaan akan melaksanakan:

1. Komitmen manajemen akan pentingnya memasyarakatkan dan memperhatikan kinerja Keselamatan dan Kesehatan Kerja.

2. Kepatuhan terhadap peraturan perundangan Keselamatan dan Kesehatan Kerja dengan menciptakan mekanisme serta prosedur Keselamatan dan Kesehatan Kerja di setiap lini bidang pekerjaan.

3. Kepastian bahwa kebijakan dan komitmen ini dilaksanakan melalui pelaksanaan menyeluruh atas kegiatan Keselamatan dan Kesehatan Kerja di seluruh unit kerja dan mensosialisasikan kepada rekanan, pelanggan, serta tamu yang berhubungan dengan perusahaan.

4. Pembinaan hubungan kerja sama, bersama instansi lain di dalam melaksanakan Keselamatan dan Kesehatan Kerja.

5. Perencanaan dan peningkatan efektivitas di dalam merancang dan membangun kegiatan usaha, perusahaan selalu berorientasi kepada Keselamatan dan Kesehatan Kerja yang terukur, terstruktur, dan terintegrasi.

6. Peningkatan kualitas sumber daya manusia melalui pendidikan dan pelatihan tentang Keselamatan dan Kesehatan Kerja, terutama di dalam memotivasi tanggung jawab individu pada pelaksanaan tugas sehari-hari.

7. Pencegahan kecelakaan kerja dan penyakit akibat kerja serta penanggulangan bencana dengan melibatkan unsur manajemen, pekerja dan Panitia Pembina Keselamatan dan Kesehatan Kerja (P2K3).

Mengingat Keselamatan dan Kesehatan Kerja merupakan tugas kita bersama (baik pekerja, pengusaha maupun pemerintah), maka perlu dibudayakan agar tercipta iklim kerja yang kondusif demi tercapainya efisiensi dan produktivitas nasional. 
PT Pura Barutama Unit Ofset sebagai perusahaan yang bergerak di bidang Printing \& Packaging, yang menerapkan Sistem Manajemen Keselamatan dan Kesehatan Kerja (SMK3). Sepakat untuk mewujudkan tempat kerja yang aman, sehat, efisien, produktif, dan ramah terhadap lingkungan melalui:

1. Mencegah kecelakaan kerja dengan target nihil kecelakaan (zero accident).

2. Mencegah terjadinya bahaya kebakaran dengan target nihil kebakaran.

3. Meningkatkan produktivitas dengan menetapkan jam service menjadi 1.500 jam pada tahun 2018.

4. Meningkatkan sumber daya manusia melalui pendidikan dan pelatihan Keselamatan dan Kesehatan Kerja (K3) secara bertahap minimal 1 kali selama 1 bulan.

5. Melakukan test kesehatan berkala kepada karyawan setahun sekali.

PT. Pura Barutama Unit Ofset memiliki struktur organisasi Panitia Pembina Keselamatan dan Kesehatan Kerja (P2K3) yang mempunyai tugas mulia agar seluruh karyawan, aset perusahaan dan Lingkungan kerja tetap terjaga dengan baik.

Organisasi P2K3 tidak boleh diisi oleh sembarang orang dan harus sesuai dengan bidangnya supaya mampu mengatasi resiko-resiko K3 yang berada di lingkungan kerja. Organisasi P2K3 memiliki beberapa job description berbeda-beda tetapi saling menunjang satu sama lain agar program K3 berjalan dengan baik. berikut job description P2K3 :

\section{Ketua P2K3 (Panitia Pembina}

\section{Keselamatan dan Kesehatan Kerja)}

1. Merencanakan, menyelenggarakan, dan memimpin semua rapat pleno reguler P2K3 atau menunjuk anggota untuk memimpinnya serta menindaklanjuti hasil rapat

2. Menentukan langkah kebijakan demi tercapainya pelaksanaan programprogram P2K3

3. Mempertanggung jawabkan pelaksanaan K3 di Perusahaan kepada kantor setempat melalui pimpinan perusahaan

4. Memonitor dan mengevaluasi pelaksanaan program-program K3 di perusahaan

5. Melaporkan kegiatan P2K3 ke menteri tenaga kerja melalui dinas tenaga kerja setempat sekurang-kurangnya 3 bulan sekali

Wakil ketua P2K3 (Panitia Pembina Keselamatan dan Kesehatan Kerja)

Melaksanakan semua tugas ketua apabila ketua berhalangan

\section{Sekretaris P2K3 (Panitia Pembina} Keselamatan dan Kesehatan Kerja) 
1. Mempersiapkan rapat reguler atau bulanan P2K3

2. Menyusun notulen rapat $\mathrm{P} 2 \mathrm{~K} 3$

3. Menghimpun semua agenda dan hasil keputusan rapat

4. Menyebarluaskan notulen rapat, laporan dan informasi K3 kepada anggota P2K3

5. Menegaskan dan mengklarifikasi hasil keputusan rapat yang telah dicapai,

6. Memberikan bantuan atau saran-saran yang diperlukan oleh tim-tim kerja demi suksesnya program K3

\section{PDD (Publikasi, Dekorasi dan}

\section{Dokumentasi)}

1. Memelihara dan mengendalikan seluruh dokumen dan data yang berhubungan dengan persyaratan $\mathrm{P} 2 \mathrm{~K} 3$

2. Melakukan identifikasi seluruh dokumen dan data sesuai status revisi terakhir untuk ditinjau dan disetujui oleh personel yang berwenang sebelum diterbitkan

3. Mengadakan perubahan dan modifikasi dokumen dan data yang dianggap perlu revisi.

4. Menetapkan dan memelihara prosedur terdokumen untuk identifikasi, koleksi, pengindekan, akses, pengarsipan, penyimpanan, pemeliharaan, dan pemusnahan rekaman mutu pasif.

\section{Administrasi}

Membantu kelancaran pelaksanaan semua tugas sekretaris dan PDD

\section{Tim Inspeksi dan Penilaian Resiko}

1. Melakukan identifikasi bahaya dan penilaian resiko terhadap barang dan jasa sebelum digunakan

2. Mengidentifikasi produk yang disediakan oleh pelanggan.

3. Menetapkan tingkat pengendalian resiko

4. Melakukan inspeksi dalam identifikasi bahaya dan membuat upaya pengendalian

5. Ikut serta dalam pelaporan dan penyelidikan penyelidikan penyakit akibat kerja dan kecelakaan serta ikut serta dalam proses konsultasi

6. Menjamin bahwa setiap pekerjaan dilakukaan dengan aman dan mengikuti setiap prosedur dan petunjuk kerja yang telah ditentukan

\section{Tim Keselamatan dan Kesehatan Kerja}

1. Memberikan pengarahan $\mathrm{P} 3 \mathrm{~K}$ kepada karyawan

2. Mengadakan pembinaan dan pelatihan P3K secara berkala kepada karyawan.

3. Mengidentifikasi, menguji, memeriksa dan memantau kesehatan karyawan dengan mengadakan check up karyawan

\section{Tim Teknik dan R\&D}

1. Melakukan penelitian mengenai hal-hal teknis yang berhubungan dengan $\mathrm{K} 3$

2. Melakukan penjadwalan pemeriksaan dan pemeliharaan sarana produksi serta perlatan yang mencakup verifikasi alatalat pengaman dan persyaratan yang 
ditetapkan oleh peraturan perundangundangan, standar dan pedoman teknis

3. Memeriksa, menguji dan memelihara secara berkala, alat dan sistem tanda bahaya keadaan darurat.

\section{Tim Konstruksi Bangunan}

1. Melakukan pemeriksaan, pemeliharaan, perawatan, dan perbaikan serta perubahan-perubahan yang dilakukan atas sarana dan prasarana perusahaan

2. Melakukan perubahan sarana dan prasarana perusahaan seusai dengan persyaratan peraturan perundangundangan yang berlaku

3. Membuat prosedur persetujuan status untuk menjamin keamanan sarana dan prasarana perusahaan saat perencanaan dan sebelum dioperasikan

\section{Tim Lingkungan Kerja}

1. Mengadakan pelatihan mengenai sumbersumber limbah atau B3 dan cara penanganannya

2. Melakukan pemantauan lingkungan baik intern (suhu ruangan, rodent pest control, dll) maupun sistem (suhu udara pabrik, curah hujan, kelembaban lingkungan pabrik, dll)

3. Membuat sistem untuk mengidentifikasi dan pemberian label pada bahan-bahan berbahaya
Tim Antisipasi dan Penanggulangan Kebakaran Serta Identifikasi Sumber

\section{Bahaya}

1. Mengontrol secara berkala petunjuk atau alat-alat yang berhubungan dengan evakuasi

2. Memberikan pengarahan kepada karyawan mengenai jalur evakuasi

3. Mengendalikan potensi-potensi bahaya disekitar lingkungan kerja atau pabrik, baik karyawan maupun peralatan yang dipakai

\section{Program Kerja Panitia Pembina Keselamatan dan Kesehatan Kerja}

Program ini sebagai wujud dari Komitmen Kebijakan dan Sasaran Keselamatan dan Kesehatan Kerja agar dapat berjalan dengan baik. berikut beberapa Program Kerja Panitia Pembina Keselamatan dan Kesehatan Kerja:

\section{Meeting Bulanan}

Program kerja ini bertujuan untuk mengevaluasi terhadap masalah-masalah yang terjadi di tempat kerja, apabila ada saran atau masukan yang membangun juga dapat disampaikan dalam program kerja ini, demi membuat perusahaan menjadi lebih baik. Program kerja ini dilakukan dalam waktu satu bulan sekali dan dilakukan oleh Panitia Pembina Keselamatan dan Kesehatan Kerja (P2K3). 


\section{Review Dokumen}

Program kerja ini bertujuan untuk mereview tentang dokumen-dokumen yang ada, apabila ada perubahan dokumen bisa disampaikan untuk melakukan perubahan yang lebih baik lagi. Review dokumen dilakukan minimal satu tahun sekali dan dilakukan oleh Pengendali Dokumen dan Data (PDD)

\section{Inspeksi K3}

Program kerja ini bertujuan untuk memonitor keselamatan dan kesehatan kerja yang ada di tempat kerja, apabila ditemukan masalah dalam penerapan K3 agar segera ditindaklanjuti dan dicari solusinya. Inspeksi K3 dilakukan dalam waktu satu bulan sekali dan dilakukan oleh Tim Inspeksi.

\section{Internal Audit}

Program kerja ini bertujuan untuk memastikan sistem Keselamatan dan Kesehatan Kerja (K3) berjalan sesuai dengan prosedur yang telah ditentukan. Internal audit ini dilakuakn oleh tim audit internal PT Pura Barutama dalam kurung waktu satu tahun sekali.

\section{Pelatihan K3 dan P3K}

Pelatihan K3 dan P3K ini bertujuan untuk meningkatkan pengetahuan dan kemampuan karyawan dalam bidang keselamatan dan kesehatan kerja, serta mengetahui, memahami, dan mengaplikasi adanya pertolongan pertama pada kecelakaan. Pelatihan K3 dan P3K diikuti

oleh semua karyawan PT Pura Barutama namun waktunya bergilir, tidak semua karyawan dalam satu waktu mengikuti pelatihan dengan tujuan tidak mengganggu waktu bekerja para pekerja. Pelatihan K3 dan P3K dilakukan dalam waktu setahun 2 kali.

\section{Tes Kesehatan Karyawan}

Tes kesehatan karyawan dilakukan dalam kurung waktu satu bulan sekali. Tes ini dilakukan dengan tujuan untuk mengetahui kondisi kesehatan para karyawan, dimana setiap departemen berbeda-beda dalam pengecekan kesehatan tersebut tergantung di departemen mana ia bekerja. Tes kesehatan ini dilakukan secara bergilir agar tidak mengganggu jam kerja.

\section{Pemantauan Lingkungan Kerja (Suhu dan} Kelembaan, Penerangan, dan Kebisingan) Pada program kerja ini yang dilakukan yaitu mengecek suhu dan kelembaban dengan alat ukur Thermal Environment Monitor, penerangan dengan alat ukur Lux Meter, dan kebisingan dengan alat ukur Sound Level Meter. Pada pengecekan suhu dan kelembaban, penerangan, dan kebisingan di PT Pura Barutama dilakukan di bagian Lipat, Finishing, Ponz, Laminasi, Cetak 1, Cetak 2, Potong Putihan, Foil, Tinta, Gudang, Mesin Varnish, Mesin Laminasi, dan Special Room. Dalam proses pengecekan tersebut PT Pura 
Barutama bekerjasama dengan Dinas Tenaga Kerja dan Transmigrasi (Disnakertrans) Kabupaten Kudus dan dilakukan dalam periode 3 bulan sekali. Tujuan dari program kerja ini adalah untuk mengetahui apakah lingkungan PT Pura Barutama aman, nyaman, dan sehat untuk para karyawan maupun warga sekitar lingkungan tempat kerja.

\section{Perawatan Infrastruktur}

Program kerja ini bertujuan agar infrastruktur tetap terjaga dengan baik dan layak terutama dalam Keselamatan dan Kesehatan Kerja (K3). Perawatan infrastruktur ini dilakukan utamanya oleh semua karyawan, khususnya bagian umum, dan perawatan gedung. Perawatan infrastruktur ini dilakukan setiap saat agar infrastruktur menjadi lebih baik lagi.

Tes COD, BOD (Chemical Oxygen Demand, Biological Oxygen Demand) Program kerja ini dilakukan dalam kurung waktu 6 bulan sekali, dalam program kerja ini yang dilakukan yakni mengecek limbah air yang dihasilkan dari PT Pura Barutama Unit Ofset, dengan tujuan untuk mengetahui apakah limbah air yang dibuang oleh perusahaan masih aman dan tidak mencemari lingkungan yang ada di sekitar perusahaan. Tes ini dilakukan oleh pihak Dinas Tenaga Kerja dan Transmigrasi (Disnakertrans) Kabupaten Kudus dan dites di Laboratorium.

\section{Simulasi Evaluasi Kebakaran}

Program kerja ini bertujuan untuk meningkatkan kemampuan dan keterampilan terhadap bahaya kebakaran. Simulasi evaluasi kebakaran ini diikutsertakan oleh karyawan dan dipandu oleh Pemadam Kebakaran (Damkar) Pura Group, dan dilakukan dalam kurung waktu satu tahun dua kali dimana pelatihan dilakukan dalam tiga waktu, yaitu:

Siang hari (saat jam kerja dan karyawan hadir semua)

Malam hari (saat hanya ada karyawan yang bekerja shift malam dan Hari libur (hanya pada saat satpam yang bertugas)

\section{Pembenahan Rambu-Rambu SMK3}

Program kerja ini bertujuan untuk mengecek apakah rambu-rambu yang sudah ada di tempat kerja masih layak atau tidak, jika sudah tidak layak maka harus diperbaiki atau bahkan diganti yang baru.

Pengecekan pembenahan ramburambu SMK3 dilakukan oleh Panitia Pembina Keselamatan dan Kesehatan Kerja (P2K3) dan waktunya adalah setiap saat, dalam arti apabila saat P2K3 melakukan pengecekan setiap harinya dan menemukan rambu-rambu yang rusak maka harus segera dibenahi.

\section{Lomba 5R (Ringkas, Rapi, Resik, Rawat, dan Rajin)}

Program kerja ini bertujuan untuk membudayakan karyawan terhadap 5R, juga 
untuk mengantisipasi perubahan yang pasti terjadi dengan peningkatan produksi, kualitas, biaya, pengiriman, keamanan, moral, dan lingkungan kerja. Lomba 5R ini diikutsertakan oleh semua departemen dan penilaiannya dilakukan dengan sistem silang personil area, misalnya bagian cetak menilai bagian varnish, bagian varnish menilai bagian lipat, bagian lipat menilai bagian ponz, dan seterusnya. Dilakukan dalam setiap bulan, dan untuk mengapresiasi dalam pelaksanaan 5R ini P2K3 menyediakan hadiah berupa uang tunai untuk departemen yang mendapatkan nilai 5R nya tertinggi.

\section{Perawatan Mesin, Pesawat Angkat-} Angkut, Bejana Tekan, dan Instalasi Gas

Program kerja ini bertujuan untuk memastikan apakah mesin dan alat lainnya masih berfungsi dengan baik atau tidak, jika tidak dapat diperbaiki atau bahkan diganti yang baru. Program kerja ini dilakukan oleh para teknisi dan yang melakukan penilaiannya PT Pura Barutama bekerja sama dengan Dinas Tenaga Kerja dan Transmigrasi (Disnakertrans) Kabupaten Kudus. Perawatan mesin, pesawat angkat-angkut, bejana tekan, dan instalasi gas dilakukan minimal satu tahun sekali.

\section{Pembenahan Pengelolaan Limbah}

Pembenahan pengelolaan limbah ini dilakukan oleh Panitia Pembina Keselamatan dan Kesehatan Kerja (P2K3), khususnya Tim
Lingkungan yang melibatkan karyawankaryawan yang bekerja di bagian Ofset. Pembenahan pengelolaan limbah ini dilakukan satu bulan sekali, dengan tujuan agar limbah yang dihasilkan dari PT Pura Barutama Unit Ofset seperti air cetak maupun cucian dari rol-rol tinta tidak mencemari lingkungan sekitar perusahaan.

Gambaran Impelementasi 5R di Perusahaan

Di PT. Pura Barutama Unit Ofset Kudus memiliki struktur organisasi 5R dimana memiliki 11 korwil (kordinator wilayah) dan beberapa PA sesuai kebutuhan di setiap wilayah.

Berikut pembagian korwil yang berada di PT Pura Barutama Unit Offset Kudus.

- Korwil 1 : area Cetak 1 dan Cetak 2

- Korwil 2 : area potong putihan, ponz, pisau dan varnish,

- Korwil 3 : area Laminasi, Kerma, foil dan lipat

- Korwil 4 : area finishing dan potong etiket

- Korwil 5 : area gudang bahan baku

- Korwil 6 : area gudang bahan jadi, Kiriman dan loading kiriman

- Korwil 7 : area proof, plate dan tinta

- Korwil 8 : area Umum, Taman, Jalan, Parkir, Ruang Makan, Ruang Sekuriti, TPS, Showroom, R. Loker, Toilet

- Korwil 9 : area administrasi dan kantor 
- Korwil 10 : area KPM, Selongsong dan cabut

- Korwil 11 : area Pura 3

Pemahaman Karyawan akan 5R pada PT Pura Barutama Unit Ofset

Pemahaman Karyawan dalam menerapkan program 5R sangat diperlukan sebab apabila karyawan tidak memahami 5R, akan sangat sulit untuk menerapkan program 5R. Penulis telah mewawancarai beberapa korwil yang telah dikasih mandat untuk menerapkan program $5 \mathrm{R}$.

\section{Penerapan 5R di Area Pra cetak}

Berdasarkan pertanyaan yang sudah Penulis buat dan Penulis amati dari area kerja tersebut Penulis mendapatkan jawaban dari beberapa korwil yang terdapat di PT Pura Barutama Unit Ofset.

Berikut jawaban dari bapak Joko Sutrisno selaku korwil 4 : area plat harus adanya rasa memiliki dan harus mempunyai rasa tanggung jawab. Di area plat ini juga saya selaku korwil harus menjalin kekeluargaan, jadi dengan adanya rasa kekeluargaan tersebut semua menjadi mudah. Seperti : semua harus bekerja sama tanpa harus saya perintah.; Tidak ada kesulitan menjalankan program 5R karena disini sudah mempunyai rasa memiliki dan sudah mempunyai rasa tanggung jawab kalau kita hanya mengandalkan dari bagian Umum kita tidak mungkin dapat mencapai semua ini.
Sebelum adanya program dari manager head office kami sudah melakukan program 5R, karena kami sadar ketika ada orang lain yang berkunjung ke area kami, kami harus memberikan rasa nyaman kepada orang tersebut. Kami tidak mau ada tamu yang merasa tidak nyaman karena area kami tidak terlihat bersih dan rapi.
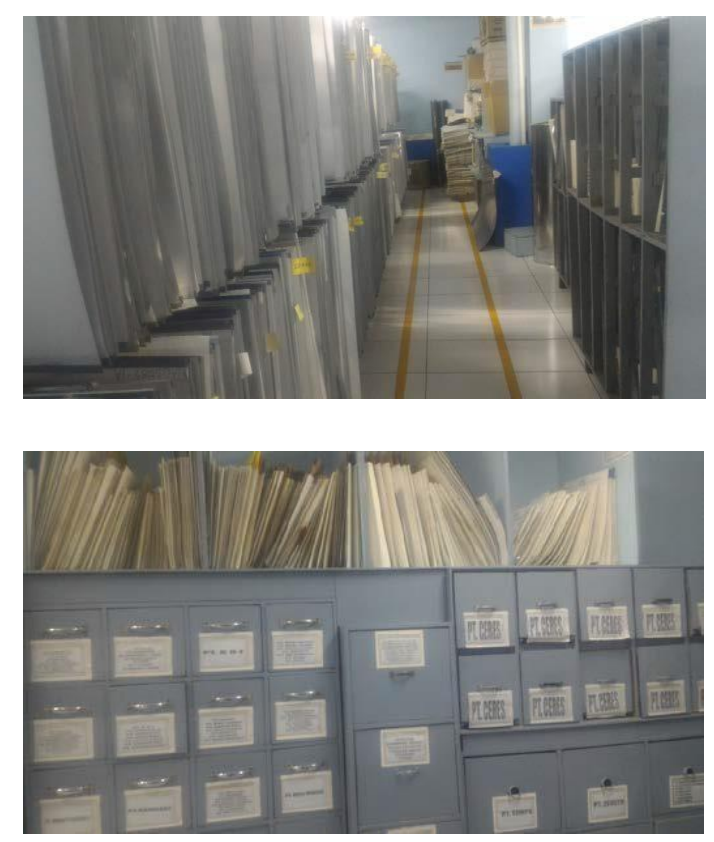

Gambar 1. Area Pelat (Dokumentasi Pribadi)

\section{Penerapan 5R di Area Cetak}

Selanjutnya penulis mendapatkan jawaban dari Bapak Andy selaku penanggung jawab area cetak 1 dengan jawaban sebagai berikut :

Penerapan program 5R di area cetak 1 biasanya ada 2 yaitu awal start mesin beroperasi dan ketika mesin dalam perbaikan sementara. Untuk awal start pengoperasian mesin biasanya dilakukan pengecekan bak 
tinta apakah terlihat baik/tidak? Pada saat beroperasi pastikan rakel dalam keadaan bersih. Untuk mesin dalam perbaikan yang biasa dilakukan adalah membersihkan body mesin dan membersihkan Gripper.

Kesulitan pasti ada karna kita harus kejar target dan target tersebut harus dipenuhi, tetapi semua program tersebut harus dilakukan karena untuk menjaga lingkungan kerja yang nyaman.

Kami sudah menerapkan 5R sebelum ada kebijakan manager head office karna 5R itu penting untuk kenyamanan saat bekerja

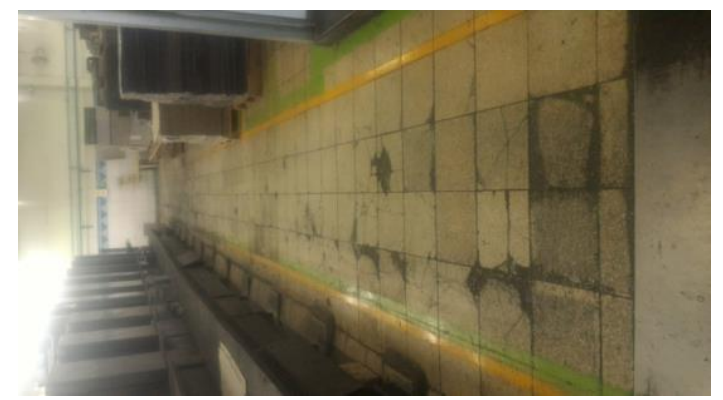

Gambar 2. Area Cetak (Sumber: dokumentasi Pribadi)

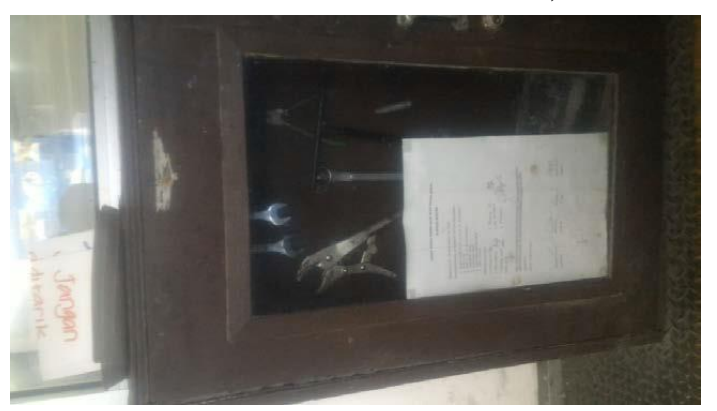

Gambar 3. Tool Box

(Sumber: Dokumentasi Pribadi)

\section{Penerapan 5R Secara Umum}

Menurut bapak Imam Haryanto selaku koordinator 5R di PT Pura Barutama Unit Ofset Kudus, program 5R (Ringkas, Rapi, Resik, Rawat dan Rajin) $50 \%$ nya adalah pekerjaan umum. Seperti memperbaiki lantai rusak, mengecat dinding, pengecatan line garis, membersihkan sawang, pembuatan tool box dll. Hal ini dilakukan untuk memberikan kenyamanan bekerja, kenyamanan bagi tamu yang akan datang, dan tentunya untuk meningkatkan efektifitas kerja, efisiensi, produktifitas dan keselamatan kerja agar produk yang dihasilkan memenuhi standar yang ditetapkan. Untuk itu perlu dibuatkan program kerja untuk pekerjaan yang bersifat umum.

\section{Pengendalian Program 5R}

Dalam menjalankan suatu program 5R diperlukan pengendalian, berupa inspeksi antar departemen dan lomba setiap bulannya. Inspeksi yang dilakukan bersifat membangun, tanpa menjatuhkan departemen yang lain. Lomba 5R dilakukan guna meningkatkan produktivitas kerja dan efisiensi kerja sebaik mungkin. Lomba 5R juga akan mendapatkan reward berupa uang tunai kepada departemen yang berhasil mendapatkan nilai tertinggi dari inspeksi tersebut.

Hasil yang ditunjukkan menghasilkan nilai yang cukup. Melihat hasil ini penulis melakukan wawancara terhadap koordinator 5R yang berada di PT Pura Barutama Unit Ofset Kudus yaitu Bapak Imam Haryanto. Menurut beliau, kesulitan untuk melaksanakan program 5R yaitu komitmen Sumber Daya Manusianya sendiri. Sistem sudah dibangun dengan baik akan tetapi komitmen akan 5R masih kurang 
baik. Menurut beliau ada beberapa faktor yang mempengaruhi komitmen tersebut: Ada yang langsung menerima perintah, Ada yang berpikir terlebih dahulu setelah menerima perintah dan Ada yang langsung menolak perintah.

Untuk mengatasi hal tersebut harus adanya kesadaran dari diri sendiri, tidak cukup hanya 1 pihak yang berdiri sendiri untuk mengatasi manajemen 5R sendiri. Bila perlu kepala bagian tanyakan langsung kepada pihak-pihak terkait seperti karyawan, operator mengenai kendalanya melaksanakan manajemen 5R. Jika belum adanya pelaksanaan manajemen 5R, maka kepala bagian perlu memikirkan pengadaan sanksi yang sudah disepakati bersama.

Berdasarkan hasil Rubrik Penilaian diatas dapat disebabkan tidak adanya komitmen dari setiap korwil untuk melaksanakan program 5R dan masih terdapatnya pemikiran bahwa program $5 \mathrm{R}$ hanya dikerjakan oleh bagian umum saja. Untuk itu dapat dilihat bahwa hasil yang dicapai dinilai hanya cukup. Melihat hasil ini, panitia 5R harus bergerak cepat untuk memperbaikinya jika ingin mendapatkan hasil yang maksimal

Kendala dalam Penerapan 5R dalam Keselamatan dan Kesehatan Kerja (K3) pada Bagian Produksi dan Cara Penyelesaiannya
Berdasarkan pengamatan yang penulis lakukan pada saat Praktik Industri di PT Pura Barutama Unit Ofset khususnya di bagian cetak, penulis melihat adanya kekurangan dalam penerapan $5 \mathrm{R}$ dalam $\mathrm{K} 3$ tersebut yang dapat menghambat proses produksi dan dapat menimbulkan kerugian sewaktu-wakktu. Kekurangan tersebut yaitu sebagai berikut :

Belum ada yang mendapatkan kategori gold pada bagian produksi pada bulan Desember 2017 sampai Februari 2018 Penyelesaiannya: Perlu adanya pendekatan dari setiap korwil kepada seluruh pekerja sehingga para pekerja selalu nyaman menjalankan program 5R yang ada di PT. Pura Barutama Unit Ofset

Masih terdapat beberapa tenaga kerja yang belum menggunakan atau bahkan tidak memakai Alat Pelindung Diri (APD) dengan benar, padahal perusahaan sudah menyediakan APD tersebut secara lengkap.

Penyelesaiannya: Perlu ditekankan atau diberi motivasi lagi kepada para tenaga kerja bahwa menggunakan Alat Pelindung Diri (APD) yang layak dan sesuai dengan ketentuan itu sangat penting untuk kesehatan diri sendiri, karena dapat meminimalisir tubuh dari Penyakit Akibat Kerja (PAK). Atau perlu lebih banyak lagi diadakan pelatihan-pelatihan tentang bahaya apabila tidak menggunakan Alat Pelindung Diri 
(APD) dengan menampilkan gambar akibat dari tidak menggunakan APD tersebut

Belum terdapat adanya Hydrant, mengingat PT Pura Barutama Unit Ofset sudah berskala Internasional dan bahayabahaya kebakaran yang dapat timbul sewaktu-waktu, maka diperlukan Hydrant agar dapat meminimalisir kebakaran meskipun sudah terdapat APAR, Pemadam Kebakaran

Penyelesaiannya: perlu dibuatkan anggaran khusus, pemetaan wilayah strategis dan pengajuan terhadap direktur untuk pemasangan Hydrant mengingat harga dari Hydrant tersebut sangat mahal tetapi memiliki fungsi yang baik guna meminimalisir nyala Api semakin membesar.

Jumlah tenaga kerja bagian umum masih terlihat sedikit karena beberapa penanggung jawab area merasa respon dari bagian umum sedikit lambat dikarenakan luas nya area perusahaan tidak sebanding dengan jumlah tenaga kerja bagian umum.

Penyelesaiannya: Pemberian wawasan terhadap semua pihak bahwa $5 \mathrm{R}$ harus dilakukan secara diri sendiri sebab area kerja kita hanya kitalah sendiri yang mengetahuinya dan perekrutan tenaga kerja untuk bagian umum.

Masker yang tersedia dilapangan pada saat digunakan jangka panjang akan sakit di telinga, mungkin itu penyebab dari karyawan tidak menggunakan masker yang diberikan

Penyelesaiannya: Mohon diganti jenis masker yang tersedia diganti dengan masker yang nyaman digunakan untuk pendek, menengah dan jangka panjang.

Masih terdapat korwil yang hanya mengandalkan bagian umum untuk melaksanakan program 5R.

Penyelesaiannya: perlu adanya komitmen dari setiap korwil dan teguran langsung dari koordinator 5R terhadap korwil tersebut. Jika sudah ditegur dan area kerja korwil tersebut masih belum adanya peningkatan perlu adanya pergantian korwil yang lebih berkomitmen dalam menjalankan program 5R.

\section{KESIMPULAN}

Berdasarkan pengamatan penulis mengenai "Implementasi manajemen 5R dalam Keselamatan dan Kesehatan Kerja (K3) di PT Pura Barutama Unit Ofset, maka penulis dapat mengambil beberapa kesimpulan berdasarkan data-data yang telah didapatkan adalah sebagai berikut :

1. Sudah terbentuknya panitia $5 \mathrm{R}$ sejak tahun 2016, diharapkan panitia tersebut dapat mempelopori anggotanya untuk selalu menerapkan 5R supaya terciptanya peningkatan produtivitas, efisiensi kerja dan lingkungan kerja menjadi nyaman 
untuk semua orang, baik karyawan dan tamu saat berkunjung.

2. Belum ada yang mendapatkan kategori gold pada bagian produksi pada bulan Desember 2017- Februari 2018. Perlu adanya pendekatan dari setiap korwil kepada seluruh pekerja sehingga para pekerja selalu nyaman menjalankan program 5R yang ada di PT. Pura Barutama Unit Ofset.

\section{Saran}

Perlu adanya komitmen dari setiap korwil dan teguran langsung dari koordinator 5R terhadap korwil tersebut. Jika sudah ditegur dan area kerja korwil tersebut masih belum adanya peningkatan perlu adanya pergantian korwil yang lebih berkomitmen dalam menjalankan program $5 \mathrm{R}$.

\section{REFERENSI}

Anonim, 2011, Buku Departemen Tenaga Kerja dan Transmigrasi R.I. (Evaluasi dan Penunjukan Calon Ahli K3) Direktorat Pengawasan Norma Keselamatan dan Kesehatan Kerja Ditjen Pembinaan Pengawasan Ketenagakerjaan Materi 1

C. Suwondo, 2012, Penerapan 5 'S' KAIZEN

Pemerintah Provinsi Jawa Tengah

Dinas Tenaga Kerja dan Transmigrasi

Balai Pengembangan Produktivitas

Tenaga Kerja)
Djamara M Tabrani, 2017, Bahan Ajar Politeknik Negeri Media Kreatif

https://sistemmanajemenkeselamatankerja.blo gsot.co.id/2013/10/pencegahankecelakaan-kerja.html

https://konveksidisidoarjo.wordpress.com/tag /contoh-wearpack/

http://netizen.media/2018/03/09/gratis-6000-masker-untuk-anak-anak-danpekerja-lapangan-di-mempawah/ https://www.produksielektronik.com/pengert ian-alat-pelindung-diri-apd-k3-jenisapd/

http://alikhananzanie.blogspot.com/2014/01/ persiapan-alat-dan-obatkuretase.html diakses pada 19 Agustus 2018 pukul 10.35

https://ergo biologi blog.wordpress.com/2012/04/26/gam bar-yang-berhubungan-denganergonomi-kerja/)

http://www.vedcmalang.com/pppptkboemlg/ index.php/menuutama/mesincnc/1129-sonnym di akses pada tanggal

http://arteducise.blogspot.com/2010/07/cont oh-laporan-hasil-penelitian.html diakses pada 19 Agustus 2018 pukul 11.30

http://www.entersafety.co.id/LOGOK3.html). 